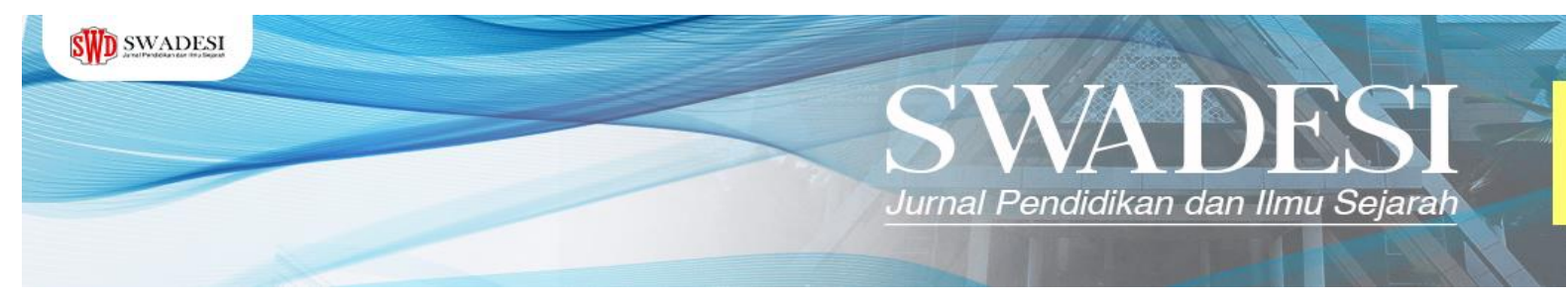

\title{
TEMON (TAMPLE MONOPOLY) : PENGENALAN CANDI BERBASIS GAMES AUGMENTED REALITY UNTUK TUNA DAKSA
}

\section{TEMON (TAMPLE MONOPOLY): INTRODUCTION TO A GAMES AUGMENTED REALITY-BASED TEMPLE FOR TUNA DAKSA}

\author{
Sidqi Alfarez ${ }^{1}$, Nurcholis Joko Prakoso ${ }^{2}$, Wahyu Sari Dewi Septianingsih ${ }^{3}$ \\ 1,2,3 Program Studi Pendidikan Sejarah, Fakultas Ilmu Sosial, Universitas Negeri Yogyakarta, Jl. Colombo \\ Yogyakarta No.1, Karang Malang, Caturtunggal, Kec. Depok, Kabupaten Sleman, Daerah Istimewa Yogyakarta \\ ${ }^{1}$ sidqialfarez.2019@student.uny.ac.id
}

\begin{abstract}
Abstrak : Tuna daksa merupakan kelainan pada sistem otot, tulang, persendian dan saraf. Hal tersebut menyebabkan adanya kesulitan tuna daksa untuk mengakses beberapa Candi di Indonesia. sebuah inovasi tersebut dirancang dengan media games sebagai pengenalan candicandi di Indonesia. Salah satu inovasi pembelajaran mengenai candi-candi di Indonesia dirancang untuk anak-anak yang berkubutuhan khusus (ABK). Maka dari itu, peneliti membuat sebuah media pengenalan candi untuk tuna daksa yakni TEMON (Tample Monopoly) media edukasi interaktif yang dapat digunakan oleh penyandang tuna daksa menikmati candi yang dilengkapi dengan games augmented reality. Adapun metode penelitian yang kami gunakan yakni ADDIE oleh Dick and Carry. Teknik Pengambilan data dilakukan dengan data primer maupun sekunder. Cara pengumpulan data dilakukan dengan penyebaran angket melalui google form dan studi literatur. Peneliti berharap bahwa penelitian ini dapat menambah ilmu dan wawasan bagi segenap masyarakat baik dalam lingkup akademisi maupun non akademisi. Khususnya penelitian ini dapat bermanfaat bagi penyandang tuna daksa.
\end{abstract}

Kata kunci: Tuna Daksa, TEMON (Tample Monopoly), Games Augmented Reality.

\begin{abstract}
Physically Disability is a disorder of the muscle, bone, joint and nervous system. This has resulted in physical difficulties accessing several temples in Indonesia. This innovation is designed with games as an introduction to temples in Indonesia. One of the learning innovations regarding temples in Indonesia is designed for children with special needs (ABK). Therefore, the researcher created a temple introduction media for the disabled, namely TEMON (Tample Monopoly) interactive educational media that can be used by persons with disabilities to enjoy the temple which is equipped with augmented reality games. The research method we use is ADDIE by Dick and Carry. The data was collected by using primary and secondary data. Data collection is done by distributing questionnaires via google form and literature studies. Researchers hope that this research can add knowledge and insights for the whole community, both academics and non-academics. In particular, this research can be useful for people with disabilities.
\end{abstract}

Keywords: Physically Disability, TEMON (Tample Monopoly), Games Augmented Reality 


\section{PENDAHULUAN}

Penyandang disabilitas di dunia cukup besar yakni kurang lebih 10\% penduduk dunia menderita disabilitas fisik, mental maupun sosial. Menurut Kementerian Ketenagakerjaan dan Transmigrasi RI menyatakan bahwa pada tahun 2010 sebanyak 7.126.409 orang penyandang disabilitas dan sebanyak 1.852.866 orang merupakan penyandang tuna daksa (Femita Adelina, 2018: 121). Kemudian pada tahun 2012 penyandang disabilitas di Indonesia menurut data PPLS (Program Perlindungan dan Layanan Sosial) sebesar 2,45\% dari jumlah penduduk dan 263.879 diantaranya merupakan penyandang tuna daksa (Diono, 2014: 32). Tuna daksa merupakan kelainan atau kecacatan pada sistem otot, tulang, persendian dan saraf. Kelainan tersebut dapat disebabkan oleh luka, penyakit, virus, dan kecelakaan, baik yang terjadi sebelum lahir, saat lahir, dan sesudah lahir. Kealinan ini menyebabkan seseorang mengalami kesulitan dalam mengoptimalkan fungsi tubuh seperti mengalami gangguan koordinasi, komunikasi, adaptasi, dan mobilisasi.

Pendidikan tidak hanya berfokus kepada anak-anak normal tetapi anak berkebutuhan khusus berhak juga mendapatkan pendidikan formal. Pemerintah Indonesia telah mengaturnya dalam UU No. 4 Tahun 1997 tentang hak pendidikan bagi penyandang disabilitas Sebuah pembelajaran sejarah terkait dengan candi-candi yang berada di Indonesia sangatlah penting dalam memberikan pendidikan sejarah berbasis games. Salah satu inovasi pembelajaran mengenai candi-candi di Indonesia dirancang untuk anak-anak yang berkubutuhan khusus $(\mathrm{ABK})$. Anak berkebutuhan khusus tersebut tergolong dalam tuna daksa yang akan menjadi sampel pengujian terhadap TEMON (Tample Monopoly) karena kesulitan aksebilitas membuat anak berkebutuhan khusus tuna daksa kurang mengenal candi-candi di Indonesia. Selain untuk mengenalkan candi kepada tuna daksa TEMON (Tample Monopoly) juga memberikan edukasi. Selain itu, TEMON (Tample Monopoly) mengenalkan candi-candi yang termasuk peninggalan sejarah yang dimiliki Indonesia untuk menumbuhkan kebanggaan dan cinta pada generasi muda.

Berdasarkan permasalahan tersebut, peneliti memiliki gagasan solutif dengan membuat sebuah media pengenalan candi untuk tuna daksa yakni TEMON (Tample Monopoly). TEMON merupakan media edukasi interaktif yang dapat digunakan oleh penyandang tuna daksa menikmati candi dengan lebih nyata karena dilengkapi dengan games augmented reality. Augmented Reality (AR) merupakan sebuah teknologi hasil gabungan benda maya tiga 2 dimensi yang dimasukkan kedalam lingkungan nyata tiga dimensi. Biasanya AR ini digunakan Jurnal Swadesi, Volume II Nomor 1 (Mei) 2021 
untuk membantu sebuah pengajaran agar seseorang dapat lebih memahami materi yang diberikan (Lia Kamelia, 2015: 238). Tunadaksa memiliki kesulitan dalam aksebilitas ke candicandi di Indonesia dengan adanya TEMON (Tample Monopoly) berbasis games augmented reality ini diharapkan mampu mengenalkan dan memberikan edukasi terkait candi kepada penyandang tuna daksa. Tujuan lain dengan adanya TEMON ini diharapkan mampu mengemas sejarah agar tidak terkesan membosankan. Sehingga penyandang tuna daksa tidak harus menikmati secara langsung bentuk candi tersebut akan tetapi dengan bentuk pemainan edukatif.

\section{METODE}

Prosedur pengembangan TEMON menggunakan model pengembangan ADDIE yang pertama kali dikenalkan oleh Dick and Carry tahun 1978 yang terdiri dari 5 tahapan. Pertama, tahap analysis yaitu penelitian dan pengumpulan data. Kedua, tahap design yaitu perencanaan terkait bagaiman bentuk media yang akan dibuat serta isi di dalamnya. Ketiga, tahap development yaitu tahap pengembangan media yang dilakukan sesuai rancangan yang telah dibuat. Keempat, tahap implementation yaitu melakukan uji coba produk kepada subyek penelitian. Kelima, tahap evaluation yaitu pada tahap ini peneliti melakukan revisi terakhir pada media yang dibuat (Endang Mulyatiningsih, 2012: 183).

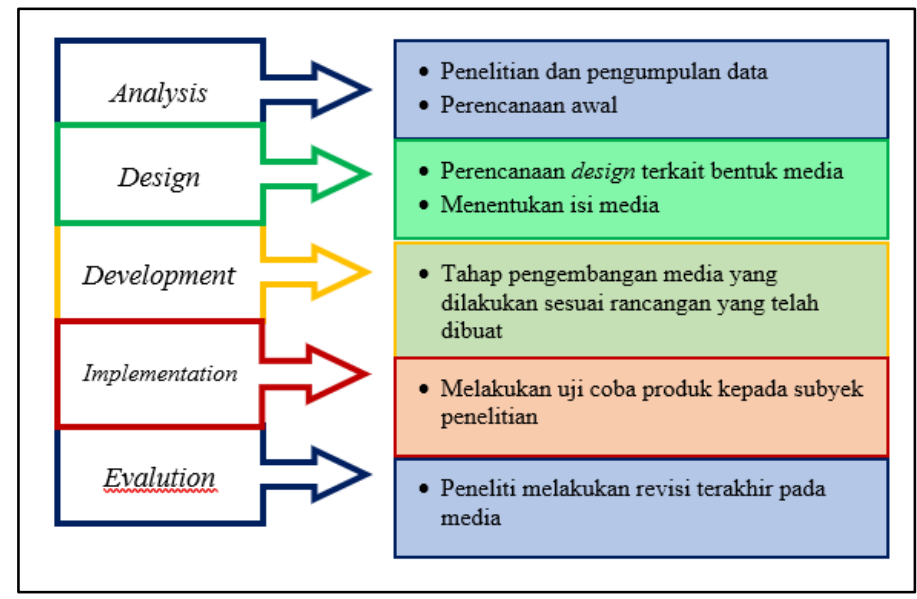

Gambar 1. Tahahapan Model Pengembangan ADDIE

1. Analysis

Proses analysis dilakukan dalam upaya untuk menentukan permasalahan dan kebutuhan pada tuna daksa apa saja dan mencoba mencari solusi dengan memenuhi kebutuhan tuna daksa. 


\section{Design}

Pada tahapan design yakni meliputi kegiatan untuk membuat produk dengan beberapa tahapan seperti pembuatan design yang diawali dengan pembuatan sektsa mengenai TEMON (Tample Monopoly) yang disesuaikan dengan kebutuhan tuna daksa. Kemudian berlanjut ke proses pencetakan TEMON (Tample Monopoly).

3. Development

Tahapan ini mengembangkan produk dengan mencari komponen yang sesuai dengan kebutuhan dalam pembuatan TEMON (Tample Monopoly). Pengembangan yang dilakukan berupa pemberian augmented reality ke dalam TEMON (Tample Monopoly).

4. Implementation

Tahap ini produk diujicobakan pada ahli media yakni pembimbing penelitian. Produk juga dapat diujikan kepada mahasiswa Fakultas Ilmu Sosial.

5. Evaluation

Evaluasi dilakukan untuk memperbaiki kekurangan dan kegagalan produk dan menambahkan hal-hal yang dirasa dapat meningkatkan kualitas produk. Agar nantinya produk dapat diimplementasikan dengan baik.

Subjek penelitian ini adalah Mahasiswa yang sedang menempuh pendidikan di Universitas Negeri Yogyakarta. Menurut Sugiyono (2009: 225), pengumpulan data dapat menggunakan sumber sumber primer dan sumber sekunder. Sumber primer penelitian ini ialah menggunakan teknik Purposive Sampling yaitu dengan pengambilan sampel berdasarkan tujuan dalam artian memilih orang-orang yang dianggap dapat mewakili tingkat signifikasi dan prosedur pengujian hipotesis. Sedangkan sumber sekundernya berupa dokumen, penelitian yang relevan, buku, jurnal, dan internet. Teknik pengumpulan data dalam penelitian TEMON ini adalah:

1. Penyebaran Angket (Via Google Form) terkumpul 30 responden dari mahasiswa program studi kependidikan.

2. Studi Literatur

Analisis data proses pengembangan produk media TEMON (Tample Monopoly) berbasis games augmented reality berupa data deskriptif, yaitu tinjuan dan saran dari ahli media sesuai dengan prosedur pengembangan yang dilakukan. Media ini nantinya akan divalidasi oleh ahli media. Kemudian, Keabsahan data penelitian ini dilakukan dengan metode 
triangulasi (Moleong, 2002: 178), yaitu triangulasi metode, sumber, dan teori. Peneliti membandingkan data lapangan berupa hasil observasi, wawancara, dan telaah dokumen.

\section{HASIL DAN PEMBAHASAN}

\section{Kebutuhan Tuna Daksa dalam Bidang Pendidikan Sejarah}

Menurut Direktorat Pendidikan Luar Biasa (2006), istilah yang sering digunakan untuk menyebutkan tunadaksa, seperti cacat fisik, cacat tubuh, tuna tubuh ataupun cacat ortopedi. Salah satu yang menyebabkan terjadinya cacat fisik (Tuna Daksa) karena adanya kelahiran yang prematur, faktor genetik, kerusakan pada sistem saraf pusat, dan terjadinya kecelakan yang menyebabkan lumpuh sehingga ditindaklanjuti dengan amputasi. Fokus permasalahan Tuna Daksa penelitian ini adalah ABK (Tuna Daksa) jenis cacat fisik seperti kehilangan salah satu bagian kakinya, lumpuh total kakinya, dan tidak bisa berjalan layaknya manusia normal. Permasalahan yang menimpa terhadap Tuna Daksa tersebut sangatlah mempengaruhi dirinya dalam melakukan kegiatan pembelajaran di lingkungan sekolah maupun lingkungan masyarakat. Kebutuhan pendidikan bagi generasi muda sangatlah penting di masa kini, termasuk juga terhadap ABK (Anak Berkebutuhan Khusus) dengan jenis Tuna Daksa. Oleh karena itu, kebutuhan akan pendidikan kini bagi Tuna Daksa sangatlah penting, tidak hanya di lingkungan sekolah mendapatkan pelajaran, tetapi juga di lingkungan masyarakat sangat berpengaruh terhadap tumbuh kembangnya bagi Tuna Daksa.

Saat ini, pemerintah sedang melakukan kebijakan keadilan dengan memperhatikan ABK (Tuna Daksa) dengan mengeluarkan beberapa Undang-Undang terkait proses pembelajaran $\mathrm{ABK}$, selain itu lingkungan masyarakat juga berperan dan berpengaruh terhadap proses belajar ABK (Tuna Daksa). Hal ini sejalan dengan konsep pendidikan Ki Hadjar Dewantara mengajukan beberapa konsep pendidikan untuk mewujudkan tercapainya tujuan pendidikan, yaitu Tri Pusat Pendidikan: (1) Pendidikan keluarga; (2) Pendidikan dalam alam perguruan; dan (3) Pendidikan dalam alam pemuda atau masyarakat (Suparlan, 2015). Salah satu kesulitan yang dialami oleh Tuna Daksa yaitu kesulitan dalam melakukan aksebilitas ke sarana-sarana vital negara atau lokal. Pembelajaran yang sangat banyak dilakukan oleh unsur lingkungan adalah pembelajaran sejarah, karena mata pelajaran sejarah banyak sekali melakukan kegiatan observasi seperti mengunjungi beberapa situs kuno bersejarah seperti candi. Oleh karena itulah dengan ABK (Tuna Daksa) mengunjungi candi yang ada di Indonesia menjadi salah satu bentuk untuk menanamkan jiwa patriotisme maupun nasionalisme, namun Jurnal Swadesi, Volume II Nomor 1 (Mei) 2021 
keterbatasan aksebilitas yang terdapat di candi karena bangunannya masih menggunakan tangga biasa layaknya candi dahulu, berbeda dengan bangunan kuno lainnya yang sudah memiliki banyak aksebilitas bagi Tuna Daksa seperti museum.

\section{Solusi Pembelajaran Sejarah Candi-Candi di Indonesia Guna Meningkatkan Efektifitas dan Efesiensi Bagi ABK (Tuna Daksa)}

Permasalahan yang dialami oleh ABK (Tuna Daksa) tersebut perlu ditindaklanjuti dalam kegiatan proses belajar sejarah mengenai bangunan candi di Indonesia. Proses pembelajaran mengenai kontruksi bangunan dari candi-candi di Indonesia sangatlah penting bagi generasi muda kini termasuk ABK (Tuna Daksa). Beragam kontruksi candi-candi sangatlah penting dipelajari bagi ABK (Tuna Daksa) mulai dari bentuk relief yang terdapat di candi, sejarah berdirinya candi, dan jenis candinya. Keterbatasan yang dimiliki oleh Tuna Daksa akibat terdapat cacat fisik di kakinya menimbulkan kesulitan untuk menjajahi candicandi yang kontruksinya banyak berupa tangga dan bangunannya yang besar maupun tinggi. Oleh karena itu penting saat ini unsur-unsur pendidikan menurut Ki Hadjar Dewantara seperti lingkungan masyarakat turut membantu proses pembelajaran sejarah candi.

Salah satu bentuk solusi yang ditawarkan untuk membantu permasalahan yang dihadapi oleh Tuna Daksa melalui beberapa cara. Caranya dengan memadukan konsep pendidikan dengan teknologi canggih, karena saat ini pembelajaran banyak menggunakan media online setelah maraknya pandemi Covid-19 maupun kemajuan teknologi atau dikenal sebagai revolusi industri 4.0. Oleh karena kondisi tersebut perlu juga inovasi teknologi yang dipadukan dengan proses pembelajaran ABK (Tuna Daksa). Bentuk dari teknologi yang menjadi solusi pendidikan bagi Tuna Daksa adalah dengan menggunakan permainan TEMON (Temple Monopoly) dengan AR (Augmented Reality). Konsep blending antara pendidikan sejarah (candi) dengan teknologi tersebut dapat mengatasi permasalahan yang dihadapi ABK (Tuna Daksa), karena dengan konsep pembelajaran tersebut dapat menambah wawasan dan pengetahuan ABK (Tuna Daksa) mengenai bentuk relief yang terdapat di candi, sejarah berdirinya candi, dan jenis candinya.

\section{Proses Pengembangan Media TEMON (Tample Monopoly)}

Penelitian pengembangan ini mengacu pada model pengembangan Dick and Carry tahun 1978 yang terdiri dari 5 tahapan. a) Tahap analysis yaitu penelitian dan pengumpulan data. b) Tahap design yaitu perencanaan terkait bagaimana bentuk media yang akan dibuat serta isi di dalamnya. c) Tahap development yaitu tahap pengembangan media yang dilakukan 
sesuai rancangan yang telah dibuat. d) tahap implementation yaitu melakukan uji coba produk kepada subyek penelitian. e) tahap evaluation yaitu pada tahap ini peneliti melakukan revisi terakhir pada media yang dibuat (Endang Mulyatiningsih, 2012: 183).

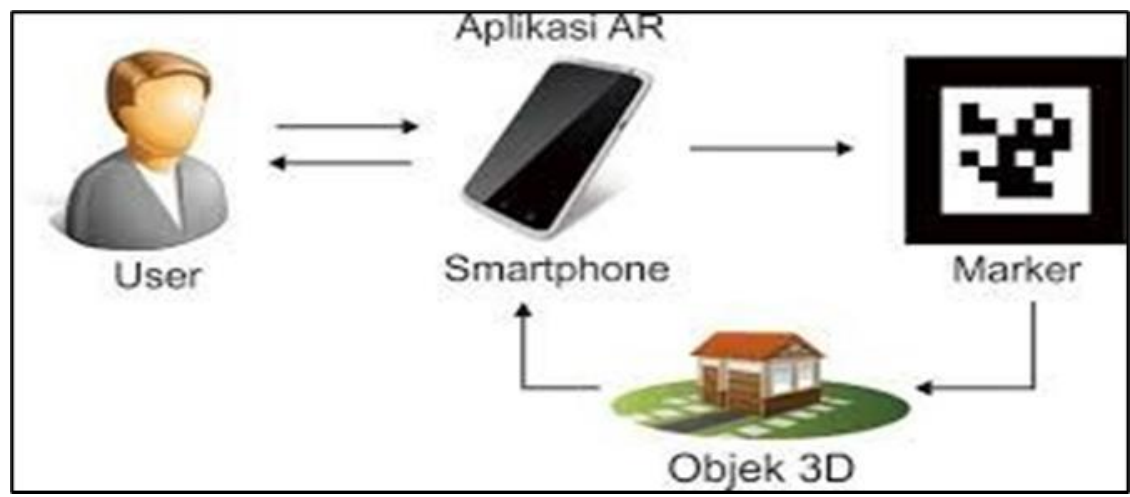

Gambar 2. Alur Penggunaan Aplikasi (Sumber: Dokumen Peneliti)

Tahap pertama adalah analysis, proses analysis dilakukan dalam upaya untuk menentukan permasalahan dan kebutuhan pada tuna daksa apa saja dan mencoba mencari solusi dengan memenuhi kebutuhan tuna daksa. Bedasarkan tahapan tersebut diperoleh bahwa tuna daksa kesulitan untuk mengakses candi seperti menaiki dan berkeliling candi. Penyandang tuna daksa kesulitan dalam mengakses candi karena ada 2 faktor yakni: 1) kecacatan yang mereka miliki sehingga menghambat untuk mengakses candi, dan 2) kontruksi candi yang identik dengan punden berundak sehingga akan menyulitkan penyandang tuna daksa untuk mengaksesnya.

Kedua adalah tahap design yakni meliputi kegiatan untuk membuat produk dengan beberapa tahapan seperti pembuatan design yang diawali dengan pembuatan sektsa mengenai TEMON (Tample Monopoly) yang disesuaikan dengan kebutuhan tuna daksa. Kemudian berlanjut ke proses pencetakan TEMON (Tample Monopoly). Kompetensi yang akan dicapai setelah menggunakan media ini adalah mampu mengilustrasikan candi secara virtual untuk penyandang tuna daksa.

Langkah-langkah yang dilakukan yaitu: 1) Melakukan sketsa awal yang nantinya adakan dijadikan acuan untuk pengembangan selanjutnya. 2) Membuat desain permainan TEMON yang nantinya bisa direvisi jika ada kekurangan. Lebih jelasnya lagi dapat dilihat dalam lampiran 1 dokumentasi pada gambar 3 dan 4 . Perbedaan desain awal dan akhir adalah digantinya kotak pertanyaan menjadi kotak kesempatan. 3) Membuat 3 jenis kartu yakni kartu 
pertanyaan, kartu pengetahuan umum, dan kartu kesempatan, dapat dilihat dalam lampiran 1 dokumentasi pada gambar 5. 4) Kemudian membuat Augmented Reality dengan memilih 2 candi dari 20 candi yang peneliti pilih, yakni ada Candi Borobudur dan Candi Singosari. Gambar candi dapat dilihat dalam lampiran 1 dokumentasi pada gambar 6 dan 7. Pemilihan kedua candi ini karena Candi Borobudur merupakan salah satu dari 7 keajaiban yang ada di dunia sehingga diharapkan anak-anak khususnya penyandnag tuna daksa mampu memiliki kebanggan terhadap Indonesia. Kemudian Candi Singosari merupakan peninggalan dari salah satu kerajaan hindu budha di Jawa Timur. 5) Penentuan marker mennggunakan desain permainan TEMON untuk memudahkan pemain.

Tahap development adalah tahap ketiga dalam tahapan ini mengembangkan produk dengan mencari komponen yang sesuai dengan kebutuhan dalam pembuatan TEMON (Tample Monopoly). Pengembangan yang dilakukan berupa pemberian augmented reality ke dalam TEMON (Tample Monopoly). Peneliti telah menentukan membuat 3 jenis kartu yakni kartu pertanyaan, kartu pengetahuan umum, dan kartu kesempatan. Kemudian membuat Augmented Reality dengan memilih 2 candi dari 20 candi yang peneliti pilih, yakni ada Candi Borobudur dan Candi Singosari. Pemilihan kedua candi ini karena Candi Borobudur merupakan salah satu dari 7 keajaiban yang ada di dunia sehingga diharapkan anak-anak khususnya penyandnag tuna daksa mampu memiliki kebanggan terhadap Indonesia. Kemudian Candi Singosari merupakan peninggalan dari salah satu kerajaan hindu budha di Jawa Timur.

Teknologi Augmented Reality mampu memasukan objek 3D kedalam lingkungan nyata (Muhammad, 2014: 267). Augmented Reality cocok digunakan untuk mengilustrasikan peristiwa atau benda peninggalan sejarah secara 3D sehingga anak dapat mempermudah dalam memahami materi secara lebih efisien dan efektif. Sistem Augmented Reality bekerja didasarkan dengan deteksi citra yang digunakan atau disebut dengan marker, contoh marker dapat dilihat dalam lampiran 1 dokumentasi pada gambar 10. Cara kerjanya adalah kamera akan mendeteksi marker yang diberikan, kamera akan melakukan perbandingan dengan database yang dimiliki. Apabila database tidak tersedia, maka informasi marker tidak akan diolah. Akan tetapi, jika database sesuai dengan marker maka akan menampilkan objek 3D atau animasi yang telah dibuat sebelumnya.

Tahap implementation merupakan tahap keempat dimana produk diujicobakan pada ahli media yakni pembimbing penelitian. Produk juga dapat diujikan kepada mahasiswa Fakultas Ilmu Sosial. Penelitian tidak bisa dilakukan dilapangan karena keterbatasan gerak Jurnal Swadesi, Volume II Nomor 1 (Mei) 2021 
akibat adanya Pandemi COVID-19. Sehingga peneliti hanya membagikan secara virtual kepada reponden untuk menguji coba. Tahap kelima adalah tahap evaluation. Evaluasi dilakukan untuk memperbaiki kekurangan dan kegagalan produk dan menambahkan hal-hal yang dirasa dapat meningkatkan kualitas produk. Agar nantinya produk dapat diimplementasikan dengan baik.

TEMON (Tample Monopoly) didesain melalui AR (Augmented Reality) sehingga menampilkan media pembelajaran sejarah menggunakan permainan monopoli. Prosedur permainan TEMON (Tample Monopoly) melalui tahapan seperti gambar yang disediakan di TEMON yang umumnya menggunakan negara-negara di dunia digantikan dengan penggunaan candi-candi di Indonesia seperti Prambanan, Borobudur, hingga Plaosan. Selain itu TEMON (Tample Monopoly) juga menerapkan sistem pertanyaan dan jawaban yang berisi mengenai candi tersebut.

Berikut adalah aturan permainan TEMON (Tample Monopoly) yang dibuat oleh peneliti, terdapat dadu dan 4 player dalam permainannya, permainan dimulai dari start. Kelengkapan Permainan:

Tabel 2. Tahapan Permainan Temon (Tample Monopoly)

\begin{tabular}{rl|l}
\hline 1. & Start & $6 . \quad$ Pulau Terpencil \\
\hline $2 . \quad$ Papan Nilai & $7 . \quad$ Penjara \\
\hline $3 . \quad 20$ Candi & $8 . \quad$ Keliling Indonesia \\
\hline $4 . \quad$ Pengetahuan Umum & $9 . \quad$ Papan nilai \\
\hline $5 . \quad$ Kesempatan & $\begin{array}{l}\text { 10. Start, setiap berhasil melewati start } \\
\text { akan mendapat poin 10. }\end{array}$ \\
\hline \multicolumn{2}{c}{ Sumber : Data Peneliti }
\end{tabular}

Terdapat 20 Candi, disetiap candi terdapat 5 poin pertanyaan. Setiap pion yang sampai disalah satu candi akan mendapat satu pertanyaan. Pemain harus menjawab pertanyaan selama 15 detik. Apabila pertanyaan berhasil dijawab pemain akan mendaptkan poin, jika pemain tidak bisa menjawab poin akan dikurangi sesuai tingkatan Candi. Candi yang paling dekat dengan start mendapat poin terendah. 


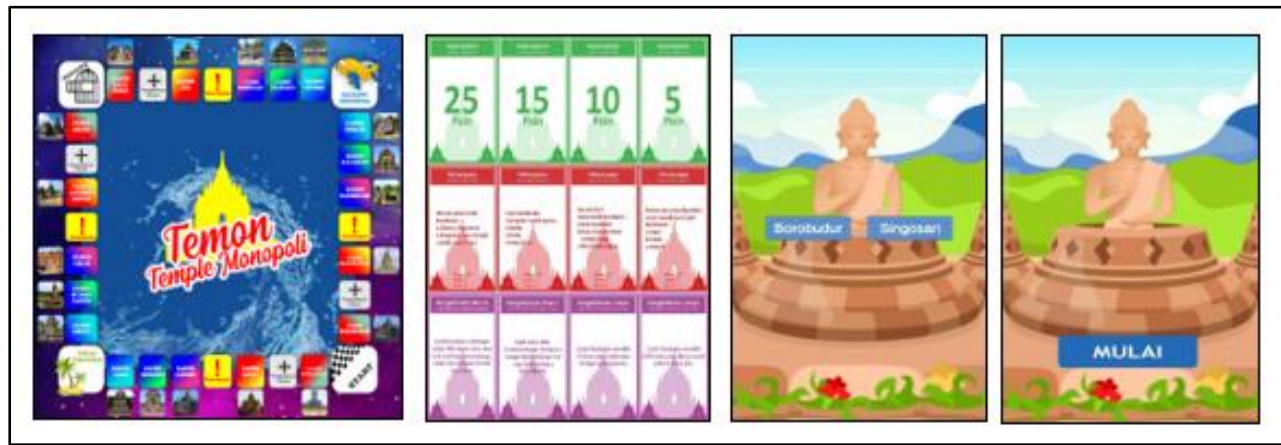

Gambar 3. Desain Monopoli (TEMON), Desain kartu TEMON, Aplikasi AR (Augmented Reality) (Sumber: Dokumen Peneliti)

Keterangan Pembagian Poin:

a. Candi Singasari-Candi Jago : jika menjawab benar akan mendapat poin 10, jika menjawab salah akan mendapat poin -5

b. Candi Kidal-Candi Dieng : jika menjawab benar akan mendapat poin 20, jika menjawab salah akan mendapat poin -10

c. Candi Ratu Boko-Candi Cetho : jika menjawab benar akan mendapat poin 30, jika menjawab salah akan mendapat poin -15

d. Candi Sukuh-Candi Borobudur : jika menjawab benar akan mendapat poin 40, jika menjawab salah akan mendapat poin -20 .

e. Pengetahuan Umum, merupakan kartu yang berisi pengetahuan umum dari setiap candi yang ada (secara acak) tidak berpengaruh ke poin.

f. Kotak Kesempatan berisi kartu yang berisi bonus-bonus poin

g. Pulau Terpencil, pemain dapat memindahkan pemain lainnya ke candi yang dia inginkan

h. Penjara, pemain harus menunggu 1 putaran untuk bebas dari penjara atau membayar dengan poin sebanyak 30 poin atau meminta bantuan ke pemain lain dengan memberikan tips 15 poin

i. Keliling Indonesia, pemain yang berhasil berada di tempat keliling Indonesia bebas memilih candi manapun sesukanya dan menjawab pertanyaan.

j. Player dinyatakan menang apabila berhasil mendapatkan nilai 200 poin

\section{Kelayakan Media TEMON (Tample Monopoly)}

Sebelum melakukan ujicoba, media pembelajaran interaktif berbasis Augmented Reality yang dikembangkan juga dievaluasi terlebih dahulu oleh ahli media. Validasi media 
dilaksanakan oleh dosen pembimbing penelitian. Validasi oleh ahli media bertujuan untuk mendapatkan informasi, kritik, dan saran agar media pembelajaran interaktif berbasis layak untuk digunakan. Augmented Reality menjadi produk yang berkualitas secara aspek program dan tampilan.

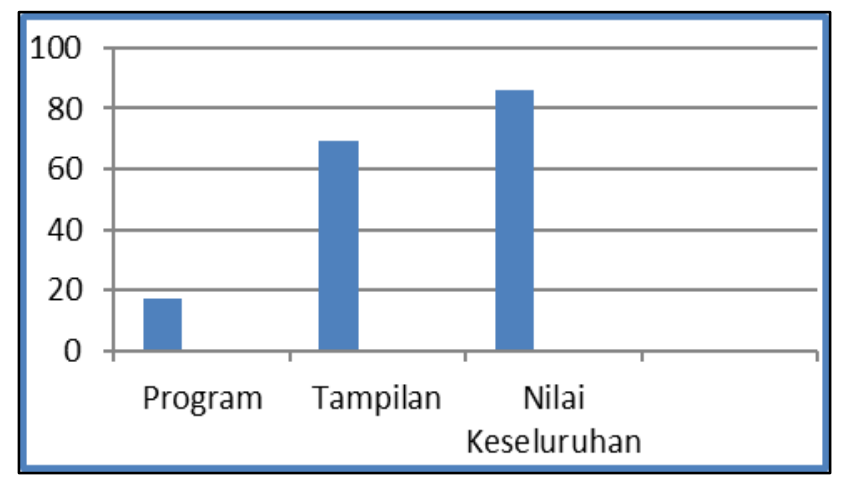

Gambar 4. Presentase Nilai dari Ahli Media (Sumber: Data Peneliti)

Tabel 2. Ketentuan Penilaian Media

\begin{tabular}{|c|c|}
\hline NILAI & KETENTUAN \\
\hline $76-100$ & SANGAT BAIK \\
\hline $51-75$ & BAIK \\
\hline $26-50$ & CUKUP \\
\hline $1-25$ & KURANG \\
\hline
\end{tabular}

(Sumber: Data Peneliti)

Tabel 2 merupakan hasil dari validasi ahli media, dengan ketentuan 5 merupakan nilai tertinggi dan 1 merupakan nilai terendah. Gambar 4 dijelaskan kembali pada tabel 2 mengenai presentasi nilai dari ahli media. Hasil dari validasi ahli media bahwa TEMON (Tample Monopoly) ini layak untuk digunakan. Aspek terkait program mendapatkan nilai 17 dan aspek tampilan mendapatkan nilai 69 dengan jumlah 86. Hasil poin tersebut ahli media menyatakan bahwa media ini layak digunakan karena tergolong kedalam sangat baik.yang sesuai dengan metode dan tujuan artikel, Penulis juga dapat menambahkan Sub judul sesuai dengan permasalahan yang dibahas, Sub-Judul ditulis dengan penulisan huruf tebal dan miring. Apabila terdapat sub-sub judul, maka sub-sub judul ditulis miring tetapi tidak tebal. Uraian tentang Hasil dan Pembahasan harus memuat rujukan/ referensi. Pembahasan harus fokus. Jika 
artikelnya melakukan ujicoba produk pembelajaran, maka hasil ujicoba sebaiknya ditampilkan dalam bentuk grafik atau pun tabel.

\section{SIMPULAN}

Berdasarkan penelitian yang dilakukan dalam TEMON (Tample Monopoly) Pengenalan Candi Berbasis Augmented Reality untuk Tuna Daksa dapat diambil sebuah kesimpulan. Dihasilkan aplikasi Augmented Reality candi yang digunakan untuk mengenalkan candi kepada penyandang tuna daksa karena keterbatasan mereka. Augmented Reality disisipan dalam permainan monopoly yang akan menambah pengetahuan dan edukasi penyandang tuna daksa terhadap candi.

Diharapkan untuk para peneliti dan juga pendidik selain fokus bagaimana materi yang akan disampaikan juga fokus pada media yang akan digunakan sehingga peserta didik lebih tertarik untuk mempelajari materi Sejarah Indonesia masa Hindu-Buddha terkait dengan peninggalan candi-candi tersebut. Serta untuk penelitian ini diharapkan mampu sebagai acuan untuk membuat games edukatif lainnya.

\section{DAFTAR PUSTAKA}

Adami, Feby Zulham. 2016. Penerapan Teknologi Augmented Reality Pada Media Pembelajaran Sistem Pencernaan Berbasis Android. Jurnal Teknik Komputer AMIK BSI. Vol 11. No.1. 122-131.

Adelina, Femita dkk. 2018. Bagiaman Agar Penyandang Tuna Daksa Mampu Menjadi Pribadi yang Bahagia. Jurnal Sains Psikologi. Jilid 7, No.2. 119-125.

Aji, A. W. 2018. Candi-Candi di Jawa Tengah dan Yogyakarta. UPT Perpustakaan Institut Seni Indonesia Yogyakarta.

Anglada, D. 2007. An Introduction to Instructional Design: Utilizing a Basic Design Modell. Tersedia pada http://www.pace.edu/ctlt/newsletter (diakses tanggal 02 Maret 2020).

Diono, A. 2014. Program Rehabilitasi Sosial Penyandang Disabilitas dan Pergeseran Paradigma Penanganan Penyandang Disabilitas. Buletin Jendela Data dan Informasi: Situasi Penyandang Disabilitas, Semester II, 2014. Kementerian Kesehatan RI.

Efendi, M. Y., Lutfi, I., Utami, I. W. P., \& Jati, S. S. P. 2018. Pengembangan Media Pembelajaran Sejarah Augmented Reality Card (Arc) Candi-Candi Masa Singhasari Berbasis Unity3D pada Pokok Materi Peninggalan Kerajaan Singhasari untuk Peserta Didik Kelas X KPR1 SMK Negeri 11 Malang. Jurnal Pendidikan Sejarah Indonesia, 1(2), 176-187. 
Maslahah, W., \& Rofiah, L. 2019. Pengembangan Bahan Ajar (Modul) Sejarah Indonesia Berbasis Candi-Candi di Blitar Untuk Meningkatkan Kesadaran Sejarah. Agastya: Jurnal Sejarah dan Pembelajarannya, 9(1), 32-43.

Moleong, L.J. 2012. Metodologi Penelitian Kualitatif. Bandung: PT Remaja Rosdakarya.

Mulyatiningsih, Endang. 2012. Metode Penelitian Terapan Bidang Pendidikan. Bandung: Alfabeta.

Munandar, A. A. 2010. Karya Sastra Jawa Kuno Yang Diabadikan Pada Relief Candi-Candi Abad Ke-13-15 M. Hubs-Asia, 10(1).

Nugraha, F. A. 2018. Desain Game Digital sebagai Media Pembelajaran Candi-Candi Kerajaan Singosari. Visualita Jurnal Online Desain Komunikasi Visual, 6(2).

Pratiwi, Imelda dan Hartosujono. 2014. Resiliensi pada Penyandang Tuna Daksa Non Bawaan. Jurnal SPIRIT. Vol.5, No.1. 48-54.

Rifa'i, Muhammad. 2014. Penerapan Teknologi Augmented Reality Pada Aplikasi Katalog Rumah Berbasis Android. Juernal Fakultas Teknik Universitas Muria Kudus. ISBN: 978-602-1180-04-4.

Sirumapea, A., Maesaroh, S., \& Saputro, K. E. 2019. Aplikasi Game Petualangan Mengenal Candi-Candi di Magelang. Jurnal Sisfotek Global, 9(1).

Sugiyono. 2009. Metode Penelitian Kuantitatif, Kualitatif, dan R\&D. Bandung: Alfabeta.

Tentama, F. 2011. Hubungan inferioritas dengan self-acceptance pada penyandang tuna daksa. Hubungan Inferioritas dengan self-acceptance pada penyandang tuna daksa. Kementerian Pendidikan Nasional: Yogyakarta

Utami, E. O., Raharjo, S. T., \& Apsari, N. C. 2018. Aksesibilitas Penyandang Tunadaksa. Prosiding Penelitian dan Pengabdian kepada Masyarakat, 5(1), 83-101.

Wendoris, Thomas. 2008. Mengenal Candi-Candi Nusantara. Yogyakarta : Penerbit Pustaka Widyatama. 